\title{
CIRCULAR ECONOMY AS A NEW WAY OF MANAGING IN THE CONDITIONS OF DIGITAL TRANSFORMATIONS
}

\author{
Nataliia Trushkina' ${ }^{1}$ Oksana Prokopyshyn²
}

\begin{abstract}
Ensuring the sustainable development of economic systems requires the introduction of organizational, management and environmentally friendly technologies, as well as innovative business models aimed at reducing the negative impact on the environment. This is in line with the concept of "green growth" proposed by the Organization for Economic Co-operation and Development. As international experience shows, an increase in the level of environmental safety of the national economy can be achieved through the introduction of fundamentally new management tools based on integrated (combination of system, process, situational, functional) approaches, the concepts of "lean" production, sustainable development. The purpose of the paper is to clarify the essence and content of the term "circular economy" on the basis of generalization and systematization of existing conceptual approaches to the definition of this concept. Methodology. The methodological basis of the study are the scientific works of foreign and Ukrainian scientists on the problems of green economy, circular economy and environmental management. The study was conducted using general scientific methods: analysis and synthesis (to generalize the existing conceptual approaches and provisions, scientific developments on the development of circular economy and ecologization of logistic systems, clarification of terminology), classification (to systematize theoretical approaches to the definition of "circular economy" proposed by various scientific schools), structural and logical generalization (to clarify the essence and content of the term "circular economy"). Results. The evolution and preconditions of formation, challenges, and factors of development of circular economy are investigated. Existing scientific approaches to the definition of the concept of "circular economy" are analyzed and summarized, which are conventionally systematized into the following groups: section of economy, paradigm, strategy, model, system, ecological opportunity, recycling technology, tool of "green" economy, and type of economic activity. The term "circular economy" is proposed to be considered from the following positions: as a modern paradigm of development of logistic systems; as a new way of management in the conditions of digital transformations; as a strategic direction of sustainable development; as an economic model based on the technology of industrial waste processing in order to achieve sustainable business models in the national economy. Practical implications. The key goal of the transition to a circular economy is a paradigm shift in logistics, rethinking the value chain and developing new business models that must meet the current requirements and challenges of the global world. The practical significance of the results of the study lies in the possibility of developing recommendations for "green" transformation of logistics systems in a circular economy and regional strategies for industrial waste management in the economic regions of Ukraine, taking into account their specificity. Value/originality. The author's approach to the formulation of the category "circular economy" is theoretically substantiated.
\end{abstract}

Key words: national economy, logistics system, green economy, circular economy, sustainable development, strategy, paradigm, waste recycling, conceptual approaches, systematization.

JEL Classification: L91, M41, P51, Q20

\section{Introduction}

Large-scale climate change, the scarcity or lack of many natural resources for doing business in the global world, and their unsustainable use over time have led to the need to restructure economic models. That is, today's business environment requires accelerating the transition to a new model, helping leading companies rethink their positions

\footnotetext{
Corresponding author:

${ }^{1}$ Institute of Industrial Economics of the National Academy of Sciences of Ukraine, Ukraine

E-mail: nata tru@ukr.net

ORCID: https://orcid.org/0000-0002-6741-7738

${ }^{2}$ Lviv National Agrarian University, Ukraine

E-mail: os378@ukr.net

ORCID: https://orcid.org/0000-0002-7027-3499
} 
and expanding the scope of the closed-loop economy.

Today this model of economic development, called the circular economy, is recognized and supported in many countries of the world in the form of political decisions, plans and practical actions. The circular economy is built on the example of the closed cycle of substances in nature and aims to maximize the value of raw materials and products before the stage of their use is over. The transition to such a system will have not only environmental but also economic benefits by creating jobs, saving money, and preventing pollution.

According to a study by the international consulting company KPMG "Future State 2030", among the global megatrends of the near future are climate change and lack of natural resources. And among the 17 UN Sustainable Development Goals, seven are aimed at overcoming environmental problems.

A 2019 survey by consulting firm $\mathrm{PwC}$ found that $41 \%$ of transportation and logistics executives in 85 countries are concerned about climate change and environmental damage related to their business growth prospects.

The World Economic Forum found that greenhouse gas emissions from logistics account for $5.5 \%$ of global greenhouse gas emissions. The UN estimates that the global transportation sector generates $25 \%$ of total greenhouse gas emissions. The total damage from the negative impact of the transport industry is $7-10 \%$ of GDP each year. The health damage caused by pollution from mobile sources is $\$ 1$ trillion a year.

Therefore, in the context of the Fourth Industrial Revolution, the paradigm of the production model is changing from linear to circular in order to ensure the sustainable development of the world. According to experts, the abandonment of traditional "use resources - produce products - dispose of waste" systems of production and consumption would generate potential economic benefits of $\$ 4.5$ trillion by 2030 .

The analysis shows that many companies around the world are already aware of the need to manage in a "new way", to transform economic models and use the mechanisms of the circular economy. Thus, $44 \%$ of the Fortune Global top-100 companies have chosen the circular economy strategy. The leaders in this are the
FMCG (Fast-Moving Consumer Goods) sector and the automotive industry. The transition to a circular economy model in companies in these areas of economic activity will help reduce raw material costs, expand markets, improve brand reputation and dialogue with customers, increase their loyalty, create a competitive business model and much more. At the same time, the petroleum industry, financial services and healthcare are not yet practicing closed-loop as extensively. At the same time, according to The Circularity Gap report, which is presented annually at the World Economic Forum in Davos, only $9 \%$ of materials in the global economy are reused.

A public opinion poll commissioned by e-commerce delivery platform Sendcloud showed that the majority of British consumers support the introduction of green technologies in manufacturing and logistics. At the same time, $38 \%$ of respondents were willing to pay extra for delivery of goods in environmentally friendly vehicles.

It should be emphasized that the COVID-19 pandemic has also forced consumers to reconsider their attitudes towards sustainable development and to consider the impact of purchases on the environment, society and business (Environmental, Social, and Corporate Governance, ESG). According to a study by internet service provider Orange Business Services, which surveyed 320 managers of international companies, $85 \%$ of respondents were willing to invest in sustainable business development. And 59\% of respondents said they cannot allow the use of unethical and unsustainable technologies, as this would affect the level of profitability of companies.

PwC's 2021 Global Consumer Behavior Survey, a rapid survey of 8,738 consumers from 22 countries, found that $55 \%$ of respondents buy from companies with clear environmental policies and $54 \%$ prefer products in environmentally friendly packaging.

Therefore, it is now necessary to look for innovative tools and implement fundamentally new approaches to the formation and development of ecosystems. The circular economy is prioritized as a new way of doing business and a key mechanism for developing and implementing a business strategy in the context of digital transformations. 


\section{Literature review and problem statement}

The concept of circular economy first became systematically mentioned in the literature of the 1960s. In 1966, the American economist K. Boulding (1966) put forward the theory of the Earth as a spaceship. "Earth, has become the only spaceship with no unlimited reservoirs, so man must find his place in the cyclic ecological system", says the author (Boulding, 1966).

The scientific work "The Limits to Growth", published in 1972 by D. Meadows et al. (1972) became another milestone in the development of the concept of circular economy. The authors' main ideas include the need to develop and produce products for efficient reuse and recycling.

In the late 1980s, the idea of the functioning of the economy as a vicious circle was revived by the efforts of a group of scientists (Stahel, Reday-Mulvey, 1981; Braungart, McDonough, 2010). These authors have also studied its impact on company competitiveness, resource savings, job creation, and waste reduction (McDonough, Braungart, 2002).

In the 1990s, one of the well-known environmental economists, D. Pierce, K. Turner (1989) joined in trying to give a clear definition of the concept of "circular economy". Later, the concepts of "cradle-to-cradle" and industrial ecology were put forward, which were similar in importance, and a contribution was made to the development of modern ideas about the circular economy (Andersen, 2007; Sherwin, 2013).

D. Reike, W. Vermeulen, S. Witjes (2018) argue that the evolutionary development of circular economy took place in three main stages:

Stage I (1970-1990), dealing with waste. In the European countries and the USA, a number of ecological legislative measures have been accepted. The concept of 3R (Reduce, Reuse, and Recycling) is beginning to generate the most interest. A principle known as "the polluter pays" is emerging. Waste management is central to this issue, but due to the lack of development of environmental culture and mentality, an approach in which the territory of less wealthy countries was used for waste disposal and / or recycling is becoming increasingly popular;

Stage II (1990-2010), environmental efficiency strategies. The idea of environmental charges (pollution charges) had some influence on the formation of the circular economy. Environmental problems were perceived by society as an economic opportunity. In the early 2000s, a number of environmental problems were recognized as global problems (depletion of the ozone layer, global warming). The scientific community is actively developing possible ways of zero-waste production, but only in industry;

Stage III (approximately 2010-present), maximum saving in an era of resource depletion. The concept of circular economy, which absorbed to the greatest extent the ideas of theoretical research, took its final form. The central problem is the threat to human survival due to the reduction and gradual disappearance of necessary natural resources, population growth, and waste. Companies are encouraged to develop with three key principles in mind: green innovation, alternative sources, and changing the industrial paradigm. Today about 500 companies in the world are implementing a circular economy strategy.

Over the past decade, proponents of the circular economy have argued that circular growth will help overcome the climate crisis and promote an inclusive green economy. The very definition of this type of economy was formulated in their 2019 study by experts from Oxford University (Haney, Krestyaninova, Love, 2019), based on a series of interviews conducted with participants in the Platform for Accelerating the Circular Economy (PACE). The experts interviewed mostly agreed that a closed-cycle economy is a regenerative type of economy, which aims to maintain the maximum possible value of products, their components and materials, the growth of which is not stimulated and does not depend on the use of limited resources. In fact, this type of economy is seen as a new trajectory for society on the road to sustainability.

Foreign scientists P. Lacy, J. Long, W. Spindler (2020) note that the circular economy is becoming a powerful tool for separating growth from the use of scarce and harmful resources, which allows increased production and consumption with less negative impact on the environment, and at the same time makes companies more innovative and competitive.

The necessity of eco-innovations support is substantiated and scientific-practical recommendations on improvement of public and private financing of ecological innovations under conditions of sustainable development globalization are given (Goncharenko, Shapoval, 2021). 
Analysis of the literature showed that the vast majority of researchers (Su et al., 2013; Reike, Vermeulen, Witjes, 2018; Kirchherr J. et al., 2018) use the particle "re" (Latin for "again") in describing the basic principles of circular economy, which characterizes the basic essence of circular economy. The circular economy was originally based on three main principles, called "3R": Reduce - Reuse - Recycle. But over time, they transformed into "9R": Rethink - Reduce Reuse - Repair - Refurbish - Remanufacturing Repurpose - Recycle - Recover.

The study and synthesis of the scientific literature shows that over the past decades of development of this scientific field scientists have not come to a unified and unambiguous interpretation of the term "circular economy". Currently, many conceptual approaches to the consideration of the ecological component of the national economy are proposed. This is due to a large number of established scientific schools, which have their own characteristics and approaches to the theoretical and applied aspects of the development of green and circular economy concepts. However, all the proposed formulations of the term "circular economy" are generally accepted and have a broader meaning that does not take into account the specifics of the functioning of logistics systems at different levels.

\section{Research methodology and purpose of the article}

The methodological basis of the study are the scientific works of foreign and Ukrainian scientists on the problems of green economy, circular economy and environmental management.

The study was conducted using the following general scientific methods: analysis and synthesis (to generalize the existing conceptual approaches and provisions, scientific developments on the development of circular economy and ecologization of logistic systems, clarification of terminology), classification (to systematize theoretical approaches to the definition of "circular economy" offered by different scientific schools), structurallogical generalization (to clarify the essence and content of the term "circular economy").

In this regard, the purpose of the article is to clarify the essence and content of the term "circular economy" on the basis of generalization and systematization of existing conceptual approaches to the definition of this concept.

\section{Presentation of the main research material}

In the scientific literature there are different points of view on the interpretation of the category "circular economy. As a rule, scientists identify it with the concepts of "circular economy", "cyclic economy", "renewable economy", "closed-loop economy", "green economy".

A number of researchers believe that the circular economy is a new stage in the development of the concept of sustainable development and the green economy in particular. On the other hand, it is much less often considered as an independent direction in economic theory, which originated in the 1970 s of the XX century.

A. Hunt, N. Dale, F. George (2019) propose two main types of definitions of the closed-loop economy. The first type is a definition in terms of resources, where the emphasis is on ensuring the closed circulation of material resources and reducing the introduction of primary, "intact" resources. The second type are definitions that refer not only to the management of material resources, but also to other aspects, such as changes in consumption patterns. Thus, the transition to a closed-loop economy is characterized by a reduction in the use of primary resources, the maintenance of the highest possible cost of materials and products, and a change in consumption patterns.

A thorough morphological analysis of the definition of "circular economy", performed by O. Shkurenko (2021), allowed the researcher to distinguish the following approaches to understanding the essence of this concept: flow and system. According to the flow approach (Yuan, Bi, Moriguichi, 2006; Geng et al., 2009; Geissdoerfer et al., 2017; Zink, Geyer, 2017), the circular economy is based on closed-loop flows of materials, energy and waste, which can be achieved through reuse of product (repair or recovery), components (reuse in production), raw materials and materials (recycling).

Representatives of the systems approach to understanding the circular economy (Ingebrigtsen, Jakobsen, 2007; Hislop. Hill, 2011; Bastien et al., 2013) consider it as a model of economic system, which is an element of the man-made system and is based on reuse of materials, which will save natural resources, and considers value creation for system elements.

According to O. Shkurenko (2021), circular economy should be understood in terms 
of a synergistic approach, which involves interdisciplinarity and integration through different industries.

Scholars generally consider the following to be circular economy:

- closed cycle economics;

- resource-based economy;

- philosophy of management;

- the concept of economic development;

- regenerative production system;

- sustainable development strategy;

- an instrument of the "green" economy;

- activities aimed at preserving the environment;

- economic activity;

- the direction of industrial modernization;

- systemic innovation approach;

- the basis of sustainable development;

- model of economic development;

- sustainable development initiative;

- economic system;

- a new way of managing;

- approach to sustainable development;

- model of circular economy;

- the economics of resource circulation;

- an integrative approach to economic growth and environmental sustainability;

- a systematic approach to economic development.
Thus, the existing scientific approaches to the definition of the term "circular economy" can be conventionally classified into 8 groups (Figure 1).

On the basis of a generalization of the terminological apparatus on the chosen topic in accordance with various scientific concepts it is proposed to consider the circular economy as an innovative approach to the organization of logistics processes based on a closed movement of resources with minimal waste losses and maximum involvement of secondary resources in production in order to achieve sustainable development of logistics systems (Dzwigol, Trushkina, Kwilinski, 2021).

This paper, as a result of research (Zaloznova, Kwilinski, Trushkina, 2018; Trushkina, 2018; Trushkina, 2019; Trushkina, 2020; Hryhorak, Trushkina, 2020; Dźwigoł, Kwilinski, Trushkina, 2021; Liashenko, Tsvirko, Trushkina, 2021; Trushkina, 2021; Hryhorak et al., 2021; Dźwigoł, Kwilinski, Trushkina, 2021; Trushkina, Krylova, Serhieieva, 2021) presents the author's approach to the formulation of the term "circular economy", which consists in considering this concept from the perspective of sustainable development, strategy, green transformation, systemic innovation approach, modeling of

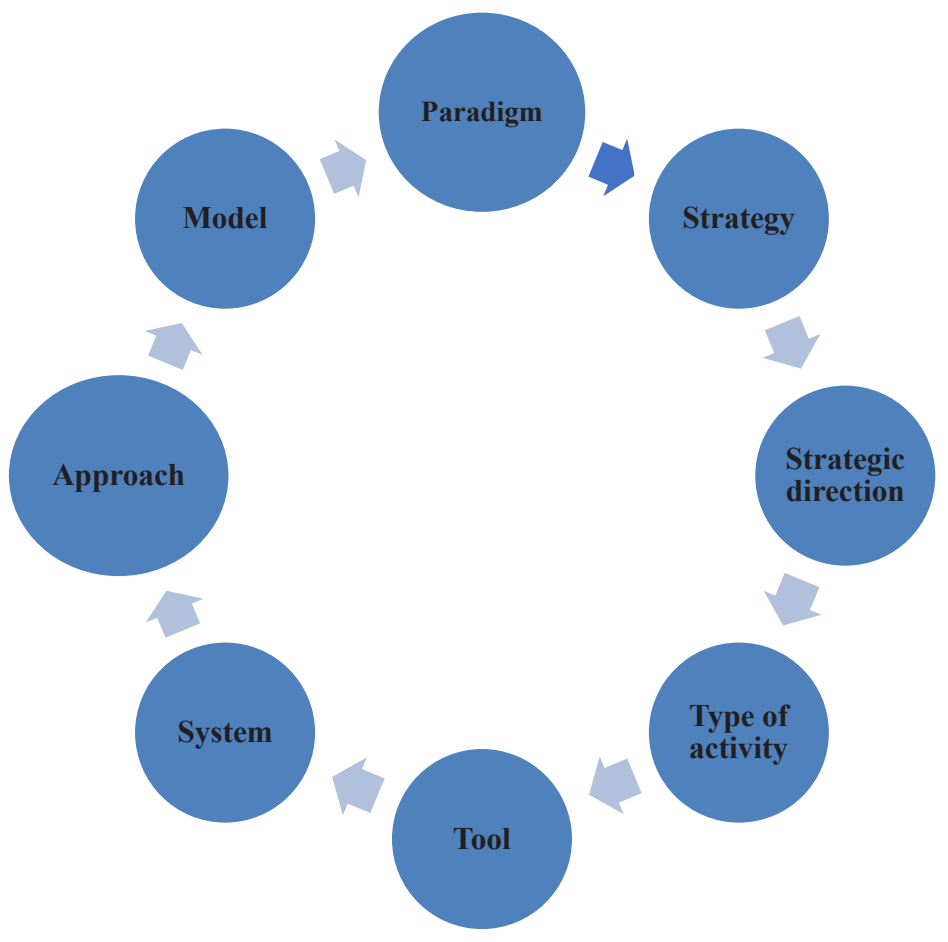

Figure 1. Systematization of approaches to the category "circular economy" proposed by representatives of various scientific schools Source: author's development 


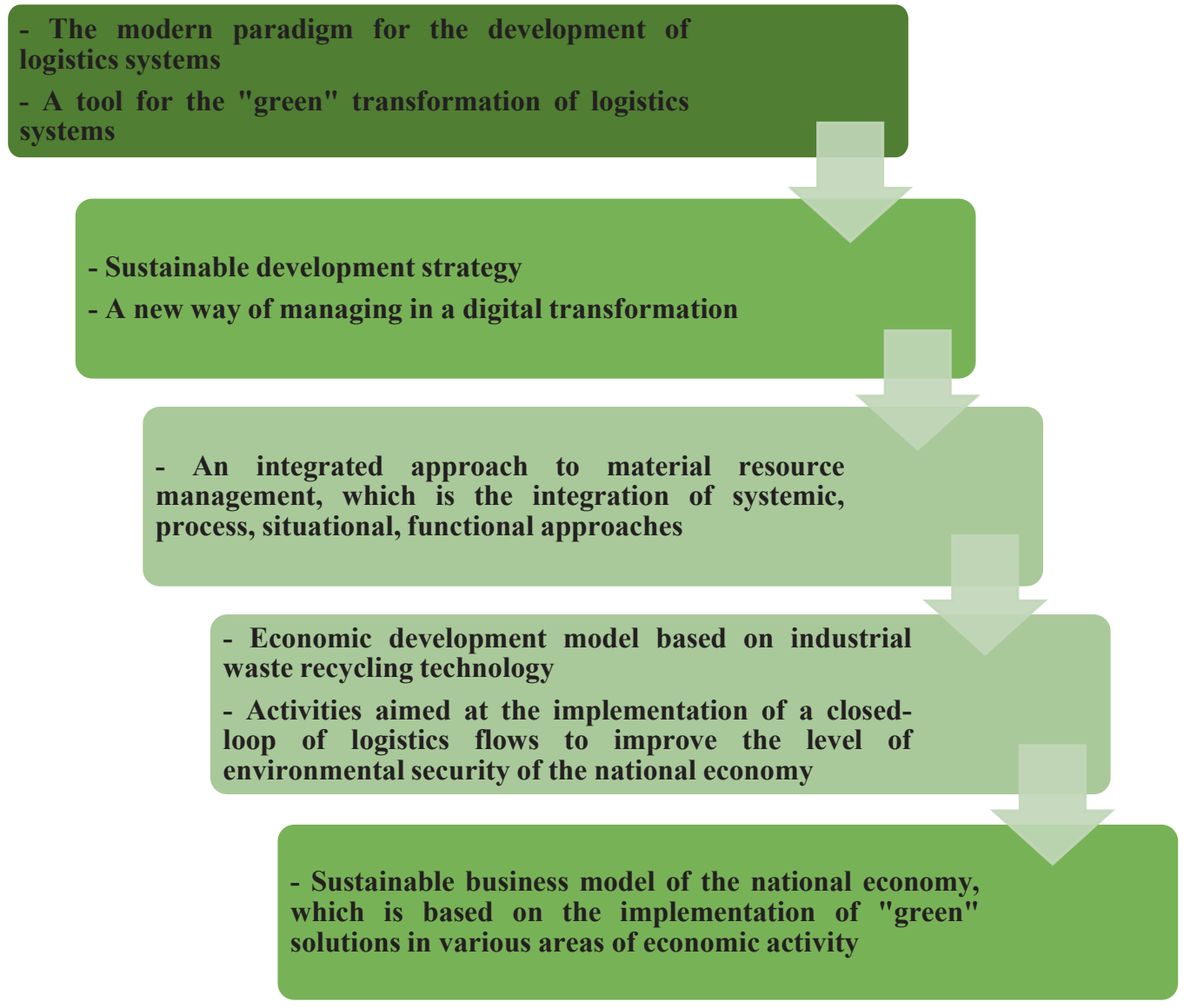

Figure 2. The author's approach to defining the concept of "circular economy"

Source: author's development

economic development, transformation of digital ecosystems (Figure 2).

\section{Conclusions}

Thus, theoretical analysis shows the need to implement the mechanism of circular economy as a concept of sustainable development and a tool of green transformation of logistics systems.

From a macroeconomic point of view, a circular economy investment strategy could lead to a $10 \%$ reduction in the cost of raw materials and a $7 \%$ increase in GDP in the European Union in 2030 compared to the usual business model (Ellen MacArthur Foundation, 2017). However, such a leap in development undoubtedly requires strategies that focus on the specific potential of the economy, as well as appropriate infrastructure and administrative capacity. An important longterm opportunity for the circular economy is the reduction of direct and indirect environmental costs. Direct costs are associated with waste disposal. But the indirect costs of using natural resources also matter. Globally, an international panel of resource experts at the United Nations Environment Program estimates these costs at up to $\$ 2.4$ trillion (Müller, Wilts, 2019).

In addition, it should be emphasized that the development of the circular economy contributes to the social effect through the creation of jobs. According to a study by the European Commission (2018), different numbers of jobs can be created depending on how waste is treated (one job can be created for 10,000 tons of used products when incinerated, six jobs when recycled, 36 jobs when reused, and up to 296 jobs when recovered and reused).

It is necessary to take into account international best practices that effectively implement applied circular economy solutions. A key goal of the transition is a paradigm shift in logistics operations, rethinking the value chain and developing new business models that must meet today's requirements and challenges in a global world. 
In further scientific research it is planned to analyze and summarize the international experience of "green" transformation of logistics systems in a circular economy; to substantiate and develop regional strategies for industrial waste management in economic regions of Ukraine, taking into account their specificity.

\section{References:}

Andersen, M. (2007). An introductory note on the environmental economics of the circular economy. Sustainability Science, vol. 2, pp. 133-140.

Bastien, R., Bohr, T., Moulia, B., \& Douady, S. (2013). Unifying model of shoot gravitropism reveals proprioception as a central feature of posture control in plants. PNAS, vol. 110, no. 2, pp. 755-760. DOI: https://doi.org/10.1073/pnas.1214301109

Boulding, K. (1966). Economic Analysis; Volume I Microeconomics (Hardcover). 4th ed. New York: Harper \& Row.

Boulding, K. (1966). The Economics of the Coming Spaceship Earth. In H. Jarrett (Ed.). Environmental Quality in a Growing Economy, Resources for the Future (pp. 3-14). Baltimore: Johns Hopkins University Press.

Braungart, M., \& McDonough, W. (2010). Cradle to cradle: Remaking the way we make things. North Point Press.

Dzwigol, H., Trushkina, N., \& Kwilinski, A. (2021). The Organizational and Economic Mechanism of Implementing the Concept of Green Logistics. Virtual Economics, vol. 4, no. 2, pp. 74-108. DOI: https://doi.org/10.34021/ve.2021.04.02(3)

Dźwigoł, H., Kwilinski, A., \& Trushkina, N. (2021). Green Logistics as a Sustainable Development Concept of Logistics Systems in a Circular Economy. In Khalid S. Soliman (Ed.), Proceedings of the 37th International Business Information Management Association (IBIMA), 1-2 April 2021 (pp. 10862-10874). Cordoba, Spain: IBIMA Publishing.

Dźwigol, H., Kwilinski, A., \& Trushkina, N. (2021). Green Logistics as a Modern Paradigm of Balanced Sustainable Development of the National Transport and Logistics System in Ukraine. In I. Tatomyr, L. Krasnii (Eds.), Green and Blue Economy on the Threshold of Digital Change: Textbook (pp. 188-205). Praha: OKTAN PRINT s.r.o.

Ellen MacArthur Foundation (2017). Achieving, Growth Within. A 320-Billion Circular Economy Investment Opportunity available to Europe up to 2025. Brüssel.

European Commission (2018). Impacts of Circular Economy Policies on the Labour Market. Final Report and Annexes. Luxembourg.

Geissdoerfer, M., Savaget, P., Bocken, N. M. P., \& Hultink, E. J. (2017). The Circular Economy a new sustainability paradigm? Clean. Prod., vol. 143, pp. 757-768. DOI: https://doi.org/10.1016/ j.jclepro.2016.12.048

Geng, Y., Zhu, Q., Doberstein, B., \& Fujita, T. (2009). Implementing China's circular economy concept at the regional level: A review of progress in Dalian, China. Waste Management, vol. 29, pp. 996-1002.

Goncharenko, N., \& Shapoval, V. (2021). Eco-innovation financing as an element of a "green" economy formation in the globalization conditions of sustainable development. Green, Blue \& Digital Economy Journal, vol. 2, no. 2, pp. 15-23. DOI: https://doi.org/10.30525/2661-5169/2021-2-3

Haney, A., Krestyaninova, O., \& Love, Ch. (2019). The Circular Economy Boundaries and Bridges. Oxford: Said Business School, University of Oxford.

Hislop, H., \& Hill, J. (2011). Reinventing the Wheel: A Circular Economy for Resource Security. Green Alliance.

Hryhorak, M. Yu., \& Trushkina, N. V. (2020). Development of the logistics system of the economic region "Polissya" in the context of the green economy: ecological problems and perspectives". Intellectualization of logistics and Supply Chain Management, no. 4, pp. 27-40. DOI: https://doi.org/10.46783/smart-scm/2020-4-3

Hryhorak, M. Yu., Dzwigol, H., Kwilinski, A., Trushkina, N., \& Ovdiienko, O. V. (2021). On the Application of the Concept of Circular Economy to Ensure Balanced Sustainable Development of the National Logistics System in Ukraine. Intellectualization of Logistics and Supply Chain Management, no. 7(8), pp. 6-25. DOI: https://doi.org/10.46783/smart-scm/2021-7(8)-1

Ingebrigtsen, S., \& Jakobsen, O. (2007). Circulation Economics: Theory and practice. Frontiers of Business Ethics, no. 3. 
Kirchherr, J., et al. (2018). Barriers to the circular economy: evidence from the European Union (EU). Ecological Economics, vol. 150, pp. 264-272. DOI: https://doi.org/10.1016/j.ecolecon.2018.04.028

Lacy, P., Long, J., \& Spindler, W. (2020). The Circular Economy Handbook: Realizing the Circular Advantage. 1st ed. Germany, Heidelberg: Springer Nature Customer Service Center GmbH.

Liashenko, V., Tsvirko, O., \& Trushkina, N. (2021) Zelena transformatsiia transportno-lohistychnoi systemy Prychornomorskoho rehionu v konteksti Yevropeiskoho Zelenoho Kursu [Green transformation of the transport and logistics system of the Black Sea region in the context of the European Green Deal]. Black Sea Economic Studies, vol. 68, pp. 64-76. DOI: https://doi.org/10.32843/bses.68-10 (in Ukrainian)

McDonough, W., \& Braungart, M. (2002). Design for the Triple Top Line: New Tools for Sustainable Commerce. Corporate Environmental Strategy, vol. 9, pp. 251-258.

Meadows, D. H., Meadows, D. L., Randers, J., \& Behrens, W. W. (1972). Limits to growth: A report for the club of Rome's project on the predicament of mankind. New York City, Universe Books Publ.

Müller, A., \& Wilts, H. (2019). Bestandsaufnahme für die erfolgreiche Planung und Umsetzung einer Kreislaufwirtschaft in Belarus. Eine Analyse von Stärken und Schwächen sowie von Chancen und Risiken im Gebiet Brest. Angefertigt vom Wuppertal Institut im Auftrag der Deutschen Gesellschaft für Internationale Zusammenarbeit (GIZ). Berlin.

Pearce, D. W., \& Turner, K. R. (1989). Economics of Natural Resources and the Environment. Johns Hopkins University Press, Baltimore.

Reike, D., Vermeulen, W. J. V., \& Witjes, S. (2018). The circular economy: New or Refurbished as CE 3.0? - Exploring Controversies in the Conceptualization of the Circular Economy through a Focus on History and Resource Value Retention Options. Resources, Conservation and Recycling, vol. 135, pp. 246-264. DOI: https://doi.org/10.1016/j.resconrec.2017.08.027

Sherwin, C. (2013). Sustainable design 2.0: new models and methods. Available at: https://www.theguardian.com/sustainable-business/blog/sustainable-design-models-methodsbiomimicry-cradle (accessed 18 October 2021).

Shkurenko, O. (2021). Integration of Sustainable Development and Business Development as a Dominant Basis of the Circular Economy Model: Theoretical Aspect. The Journal of $V$. N. Karazin Kharkiv National University. Series: International Relations. Economics. Country Studies. Tourism, vol. 13, pp. 152-165. DOI: https://doi.org/10.26565/2310-9513-2021-13-16

Stahel, W. R., \& Reday-Mulvey, G. (1981). Jobs for tomorrow: the potential for substituting manpower for energy. New York: Vantage Press.

Su, B., Heshmati, A., Geng, Y., \& Yu, X. (2013). A review of the circular economy in China: Moving from rhetoric to implementation. J. Clean. Prod., vol. 42, pp. 215-227.

Trushkina, N. (2018). Green logistics as a tool to improve the quality of life in conditions of globalization. Contemporary Problems of Improve Living Standards in a Globalized World: Volume of Scientific Papers (pp. 147-152). Opole, Publishing House WSZiA.

Trushkina, N. V. (2019). Green logistics as a component of corporate social responsibility of business. III International Scientific Conference The Modern Trends in the Development of Business-Social Responsibility: Conference Proceedings, June 28th, 2019, Nova School of Business and Economics, Lisbon, Portugal (pp. 112-115). Riga: Baltija Publishing. (in Russian)

Trushkina, N. (2020). International experience in implementing the mechanism of "green" financing for sustainable development of transport and logistics systems. Competitiveness and sustainable development: Book of abstracts of the 2nd Economic International Conference, Chisinau, Republic of Moldova, November 20th, 2020 (pp. 10). Chişinău: Tehnica-UTM.

Trushkina, N. V. (2021). Circular Economics: Concept Formation, Evolution of Development, Barriers, Problems and Prospects. Visnyk ekonomichnoi nauky Ukrainy, vol. 1(40), pp. 9-20. DOI: https://doi.org/10.37405/1729-7206.2021.1(40).9-20 (in Ukrainian)

Trushkina, N., Krylova, O., \& Serhieieva, O. (2021). Green Investments as a Tool for Financial Support of the Regional Transport and Logistics System. In I. Tatomyr, L. Krasnii (Eds.), Green and Blue Economy on the Threshold of Digital Change: textbook (pp. 205-218). Praha: OKTAN PRINT s.r.o.

WHO (2019). Circular economy and health: opportunities and risks. Copenhagen: WHO Regional Office for Europe.

Yuan, Z., Bi, J., \& Moriguichi, Y. (2006). The circular economy: A new development strategy in China. Journal of Industrial Ecology, vol. 10, pp. 4-8.

Zaloznova, Yu., Kwilinski, A., \& Trushkina, N. (2018). Reverse logistics in a system of the circular economy: theoretical aspect. Economic Herald of the Donbas, no. 4(54), pp. 29-37.

Zink, T., \& Geyer, R. (2017). Circular economy rebound. Journal of Industrial Ecology, vol. 21, pp. 593-602. 